Normandie M. Chubra-Smith MD FRCPC,

Raymer P. Grant MD FRCPC, Leonard C. Jenkins MD FRCPC

\title{
Perioperative transcutaneous oxygen monitoring in thoracic anaesthesia
}

Transcutaneous axygen tension $\left(\mathrm{PtCO}_{2}\right)$ was measured in 30 patients scheduled for elective pulmonary resection requiring one-lung ventilation during anaesthesia. Simultaneous $\mathrm{PtCO}_{2}$ and arterial axygen tension $\left(\mathrm{PaO}_{2}\right)$ measurements were taken preoperatively (preop), intraoperatively during two-lung endotracheal (ET) and onelung endobronchial ventilation (EB), and postoperatively (postop). There was a significant correlation ( $r$ ) between $\mathrm{PtcO}_{2}$ and $\mathrm{PaO}_{2}$ at all time periods: 0.97 (preop); 0.91 (ET);0.83 (EB);0.81 (postop). There were no significant differences among the transcutaneous oxygen indices $\left(\iota \mathrm{O}_{2}\right.$ index $\left.=\mathrm{PtCO}_{2} / \mathrm{PaO}_{2}\right)$ in the preop $(0.69 \pm 0.09)$, ET $(0.68 \pm 0.10)$ and postop $(0.71 \pm 0.12)$ time period. The $\mathrm{tcO}_{2}$ index was significantly lower during one-lung anaesthesia $(0.61 \pm 0.14)$. The $\mathrm{PtcO}_{2}$ was consistently lower than the corresponding $\mathrm{PaO}_{2}$ measurement, thus providing a continuous estimation of the "minimum" $\mathrm{PaO}_{2}$ level throughout anaesthesia and recovery. In four patients a marked drop in $\mathrm{PtcO}_{2}$ occurred just after the initiation of one-lung ventilation. In three, this was associated with arterial hypoxaemia and in one, haemodynamic compromise. In all four cases the $\mathrm{PtcO}_{2}$ was the

\section{Key words}

ANAESTHETIC TECHNIQUES: one-lung, endobronchial; MEASUREMENT TECHNIQUES: transcutaneous $\mathrm{PO}_{2}$; MONITORING: oxygen; OXYGEN: hypoxia, tension.

From the Department of Anaesthesiology, The University of British Columbia and Vancouver General Hospital, Vancouver, British Columbia.

Address correspondence to: Dr. N.M. Chubra-Smith, Department of Anaesthesia, Burnaby General Hospital, 3935 Kincaid Street, Burnaby, British Columbia, Canada V5G $2 X 6$. first monitored parameter to change. As there is a substantial risk of developing hypoxaemia during thor. acic anaesthesia, $\mathrm{PtcO}_{2}$ monitoring provides valuable early warning of impending hypoxaemia or haemodynamic compromise, thereby facilitating early therapeutic intervention.

During anaesthesia for thoracotomy, one-lung endobronchial ventilation is not infrequently associated with marked decreases in $\mathrm{PaO}_{2}$. Hypoxaemia may result from intrapulmonary shunting, from changes in hypoxic pulmonary vasoconstricton, from atelectasis in the dependent lung and from surgical manipulation impairing ventilation or cardiac output. ${ }^{\text {I }}$

Previous studies have shown that in haemodynamically stable adults transcutaneous oxygen tension $\left(\mathrm{PtcO}_{2}\right)$ correlates well with arterial oxygen tension $\left(\mathrm{PaO}_{2}\right)^{2,3}$ In patients with cardiac compromise $\mathrm{PtcO}_{2}$ is more a reflection of cardiac output and oxygen delivery to the tissues than of $\mathrm{PaO}_{2}{ }^{4,5}$

Transcutaneous oxygen monitoring during anaesthesia for thoracic surgery has been shown to be a valuable trend indicator when two-lung ventilation is utilized. ${ }^{6}$ Previous investigators have also suggested that $\mathrm{PtcO}_{2}$ monitoring is of value during one-lung ventilation. ${ }^{7,8}$ In the latter study, however, only two or three paired measurements of $\mathrm{PtcO}_{2}$ and $\mathrm{PaO}_{2}$ were made in each patient during one-lung ventilation. ${ }^{8}$ The purpose of the present study was to examine the relationship between $\mathrm{PtcO}_{2}$ and $\mathrm{PaO}_{2}$ in patients undergoing thoracotomy where one-lung ventilation was utilized, and to examine whether or not that relationship was altered by changing from two-lung ventilation to one-lung ventilation. 


\section{Methods}

Thirty ASA physical status II to IV patients aged 41 to 76 years admitted for elective thoracotomy and lung resection were studied. Patients with a history of cardiac failure or with any degree of cardiac compromise preoperatively were excluded. The study was approved by the Screening Committee for Research Involving Human Subjects of The University of British Columbia and by the Vancouver General Hospital Clinical Research Committee. Written informed consent was obtained from each patient prior to inclusion in the study.

Patients were assessed the day before surgery and blood pressure, heart rate (HR) and oral temperature were recorded. A combined transcutaneous oxygen $\left(\mathrm{PtcO}_{2}\right)$ and carbon dioxide monitor, Biochem Lifespan \# 100 (Waukesha, WI), was used for measuring $\mathrm{PtcO}_{2}$. The oxygen sensor, a polarographic electrode with a platinum cathode and silver anode, polarized with 0.6 volts and covered with a potassium chloride electrolyte and semi-permeable polypropylene membrane, was calibrated at $44^{\circ} \mathrm{C}$ to an internal electronic zero and to 21 per cent by exposure to room air. Electrode temperature was monitored and maintained at $44^{\circ} \mathrm{C}$ by an internal thermistor. The patients' shoulders or infraclavicular areas were used for placement of the $\mathrm{PtcO}_{2}$ sensors. The site was wiped and alcohol, a drop of contact gel was placed on the skin and the $\mathrm{PtcO}_{2}$ sensor was fixed to the site using a double-sided adhesive $\mathrm{O}$-ring. Twenty minutes were allowed for warm up and stabilization of the $\mathrm{PtcO}_{2}$ sensor before a measurement with the patient breathing room air was recorded.

At the same time an arterial blood sample was drawn by percutaneous puncture of a radial artery with a preheparinized syringe. The blood sample was buried in ice and analyzed within 20 minutes by the hospital laboratory with a Radiometer ABL 3 analyzer. Results were corrected for patient temperature and haemoglobin values. After recording the first measurements, patients were placed on supplemental oxygen by Venturi mask. The first ten patients received an inspired oxygen concentration $\left(\mathrm{FrO}_{2}\right)$ of 0.3 , the next eight patients 0.5 , and the final eight 1.0. After waiting 15 minutes for stabilization, the $\mathrm{PtcO}_{2}$ was recorded and another arterial blood sample was drawn for measurement of $\mathrm{PaO}_{2}$. Four patients refused to allow a second arterial blood gas measurement.
On the day of surgery the patients were premedicated with a benzodiazepine one hour preoperatively. In the operating room the $\mathrm{PtcO}_{2}$ sensor was calibrated and placed on the patient's shoulders in the same fashion as described above. A \#20 gauge catheter was placed percutaneously in a radial artery prior to anaesthetic induction; heart rate and blood pressure were monitored continuously utilizing an Electronics for Medicine PM-2B monitor and Cobe disposable pressure transducer.

Placement of the $\mathrm{PtcO}_{2}$ sensor was restricted to the patients' shoulders and infraclavicular areas of the chest. Sites were changed and prepared every four hours, as recommended by the manufacturer. The sensor underwent two-point calibration with each sensor site change. A continuous strip recording of $\mathrm{PtcO}_{2}$ for the duration of the study period was obtained for each patient.

Anaesthesia was induced with thiopentone and fentanyl. Endobronchial intubation with a double lumen tube (National Catheter Broncho-Cath) was facilitated by administration of succinylcholine. Correct positioning of the double lumen tube was confirmed using a paediatric fiberoptic bronchoscope. Anaesthesia was maintained with oxygen, isoflurane, nitrous oxide, fentanyl and pancuronium. Patients were mechanically ventilated with a tidal volume of $8-10 \mathrm{ml} \cdot \mathrm{kg}^{-1}$. Ventilation was adjusted to maintain the arterial carbon dioxide tension between 36 and 42 torr. Immediately after induction an oesophageal stethoscope/temperature probe was inserted into the mid-oesophagus and temperature was continuously monitored. The $\mathrm{FrO}_{2}$ was monitored using a Critikon oxygen analyzer (Oxychek) with the sensor in the inspiratory limb on the circle circuit and was calibrated prior to use of room air and 100 per cent oxygen.

At the time of induction and every 15 to 20 minutes thereafter, a set of measurements (HR, MAP, temperature, $\mathrm{FIO}_{2}, \mathrm{PtcO}_{2}$ and $\mathrm{PaO}_{2}$ ) were recorded. At least ten minutes were allowed for the $\mathrm{PtcO}_{2}$ sensor to stabilize after a change in $\mathrm{FrO}_{2}$ before another set of measurements were made. After induction the $\mathrm{FIO}_{2}$ was adjusted to $0.4 ; \mathrm{FIO}_{2}$ was increased to 0.5 after skin incision. Fifteen to 20 minutes prior to the initiation of one-lung endobronchial ventilation (EB) the $\mathrm{FIO}_{2}$ was increased to 1.0 and a set of measurements was made. After 15 minutes of EB ventilation of $\mathrm{FrO}_{2}=1.0$ the measurements were repeated. If the $\mathrm{PtcO}_{2}$ was 


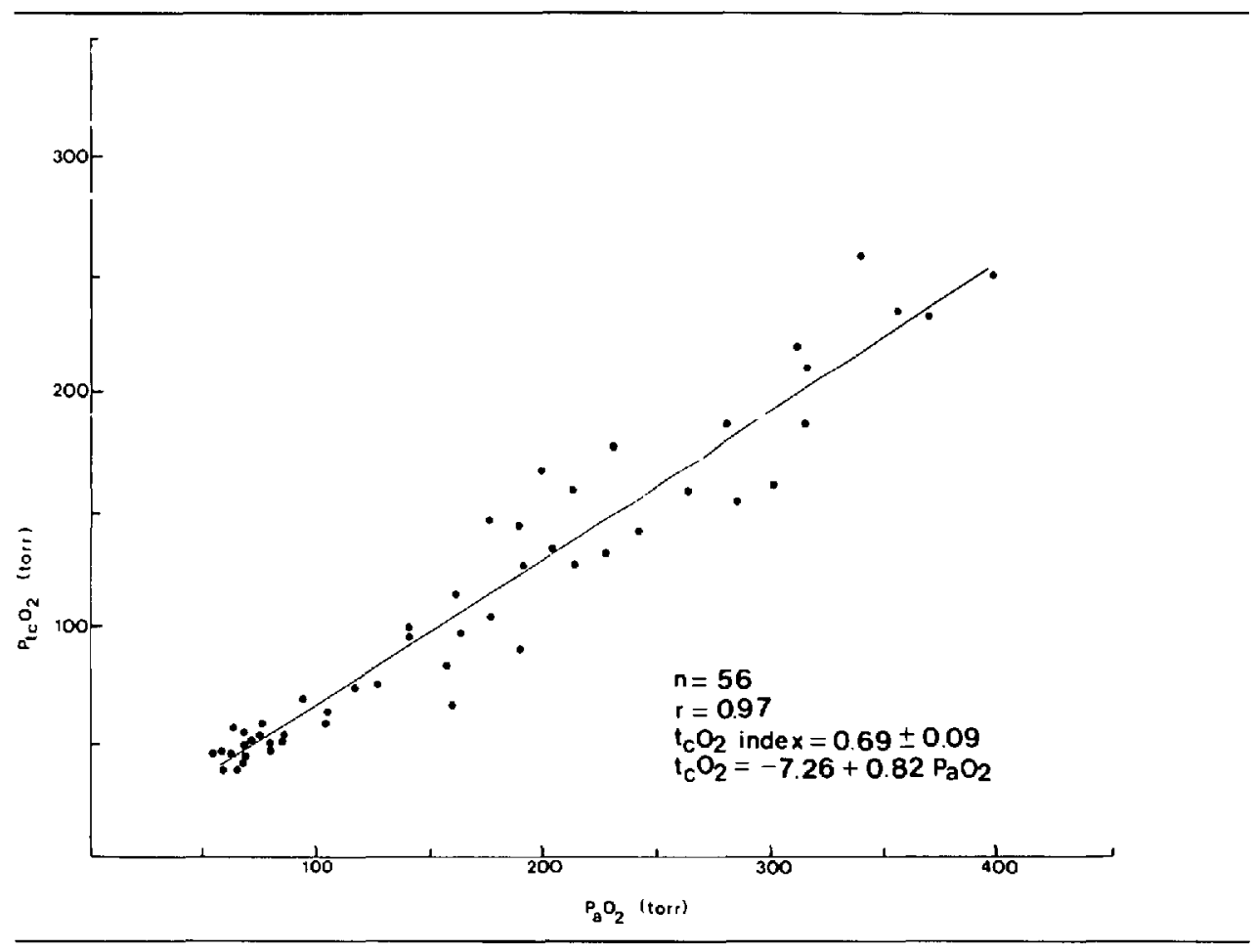

FIGURE 1 Preoperative relationship between transcutaneous $\left(\mathrm{PtcO}_{2}\right)$ and arterial oxygen tension $\left(\mathrm{PaO}_{2}\right)$.

greater than 100 torr, then the $\mathrm{FIO}_{2}$ was varied at the discretion of the attending anaesthetist. During EB ventilation, if the $\mathrm{PtcO}_{2}$ dropped below 75 torr, the $\mathrm{FIO}_{2}$ was immediately returned to 1.0 . When two-lung endotracheal ventilation (ET) was resumed, further measurements of $\mathrm{PtcO}_{2}$ and $\mathrm{PaO}_{2}$ were made with the $\mathrm{FIO}_{2}$ ranging from 0.4 to 1.0.

At the end of the surgical procedure residual neuromuscular blockade was reversed and $26 \mathrm{pa}-$ tients were extubated in the operating room. The remaining four patients required a short period of mechanical ventilation (2-4 hours) in the recovery room, prior to extubation. In the recovery room further measurements were made every three hours for a period of 18 to 24 hours. Additional measurements were made if indicated by the patient's condition.

\section{Data analysis}

The measurements recorded were separated into four time periods for analysis: preoperative (preop), intraoperative two-lung endotracheal ventilation
(ET), intraoperative one-lung ventilation (EB), and postoperative (postop). There were no significant differences in any of the measured parameters during two-lung ventilation prior to the period of one-lung ventilation versus two-lung ventilation after one-lung ventilation; thus all the results for two-lung ventilation are presented together as the ET time period in the figures and the text.

The mean and standard deviation of HR, MAP, temperature and transcutaneous oxygen index $\left(\mathrm{tcO}_{2}\right.$ index $=\mathrm{PtcO}_{2} / \mathrm{PaO}_{2}$ ) were determined for each time period and compared using analysis of variance and the two-tailed Student's t-test. A p value $<$ 0.05 was considered significant.

\section{Results}

Nineteen males and 11 females were studied. Mean age was $63.5 \pm 10.2$ years. Eight pneumonectomies and 22 lobectomies were performed. A total of 527 paired measurements of $\mathrm{PtcO}_{2}$ and $\mathrm{PaO}_{2}$ were made with 56 in the preop, 159 in the ET, 132 in the $\mathrm{EB}$ and 180 in the postop time periods. 


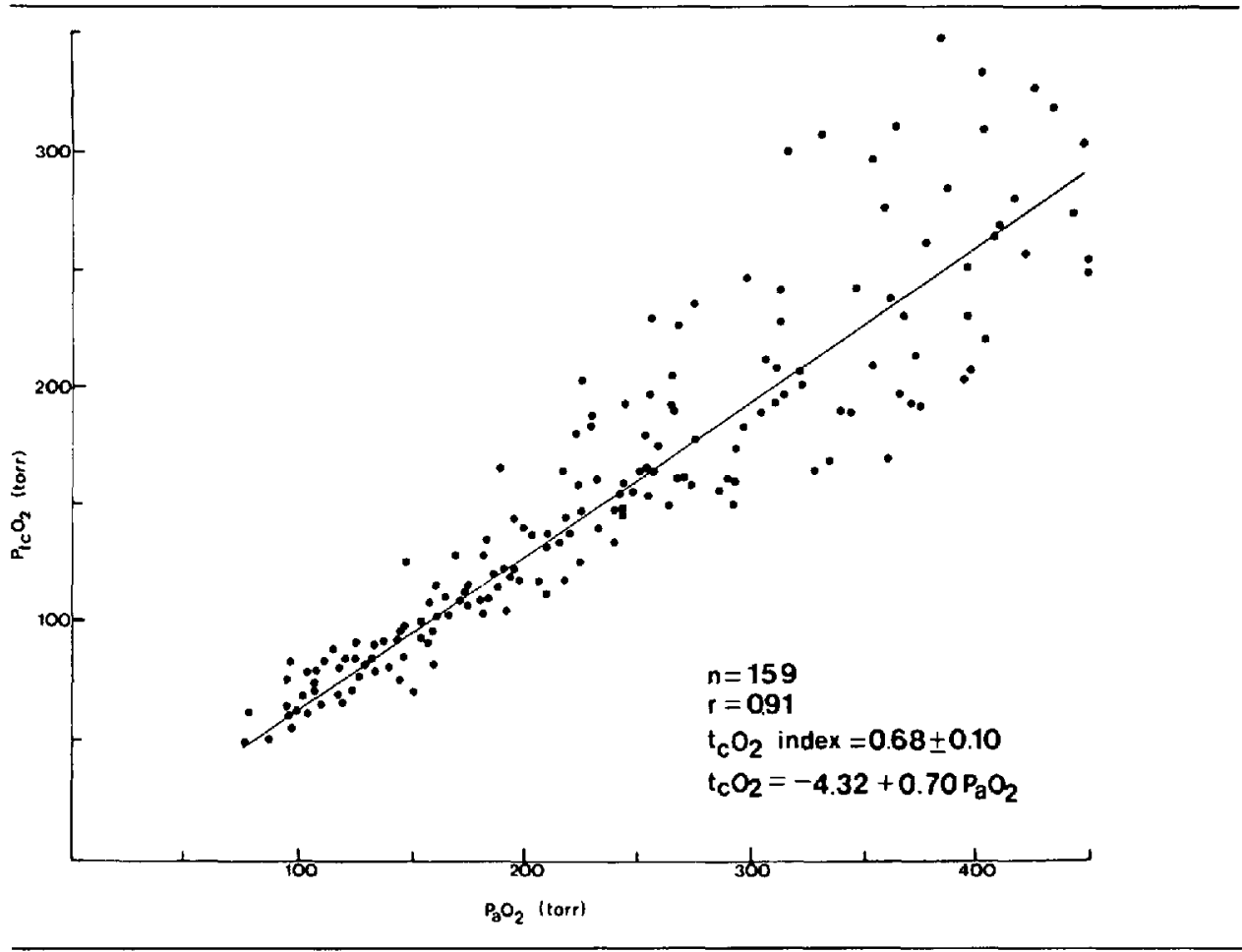

FIGURE 2 Intraoperative relationship between transcutaneous $\left(\mathrm{PtcO}_{2}\right)$ and arterial oxygen tension $\left(\mathrm{PaO} \mathrm{O}_{2}\right)$ during endotracheal anaesthesia (two-lung ventilation) for thoracotomy.

The results are summarized in the Table. There were no significant differences among the four time periods for mean HR, MAP and temperature. There was a significant correlation $(p<0.001)$ between $\mathrm{PtcO}_{2}$ and $\mathrm{PaO}_{2}$ for each time period of the study (Figures 1-4): $r$ values were 0.97 (preop), 0.91 (postop), 0.83 (EB) and 0.81 (postop). The $\mathrm{tcO}_{2}$ indices were $0.69 \pm 0.09$ (preop), $0.68 \pm 0.10$ (ET), $0.61 \pm 0.14$ (EB) and $0.71 \pm 0.12$ (postop). The $\mathrm{tcO}_{2}$ index was significantly lower during EB ventilation than during the other time periods $(\mathrm{p}<$ $0.001)$. The variance of the $\mathrm{tcO}_{2}$ index was also noted to be greater during the EB time period.

The 90 per cent response time of $\mathrm{PtcO}_{2}$ to

TABLE Results

\begin{tabular}{|c|c|c|c|c|c|c|}
\hline & \multirow[b]{2}{*}{ Pre-op } & \multicolumn{3}{|c|}{ Endotracheal (two-lung) } & \multirow[b]{2}{*}{$\begin{array}{l}\text { Endobronchial } \\
\text { one-lung }\end{array}$} & \multirow[b]{2}{*}{ Post-op } \\
\hline & & $\begin{array}{l}\text { Pre } \\
\text { one-lung }\end{array}$ & $\begin{array}{l}\text { Post } \\
\text { one-lung }\end{array}$ & Total & & \\
\hline Total samples (n) & 56 & 108 & 51 & 159 & 132 & 180 \\
\hline Temperature $\left({ }^{\circ} \mathrm{C}\right)$ & $36.8 \pm 0.2$ & $35.9 \pm 0.5$ & $35.2 \pm 0.4$ & $35.6 \pm 0.8$ & $35.3 \pm 0.6$ & $36.0 \pm 0.5$ \\
\hline $\mathrm{PaO}_{2}$ (tor) & $131 \pm 78$ & $238 \pm 95^{*}$ & $240 \pm 90^{*}$ & $242 \pm 99^{*}$ & $200 \pm 94^{*}$ & $138 \pm 46$ \\
\hline $\mathrm{tcO}_{2}$ index & $0.69 \pm 0.09$ & $0.68 \pm 0.10$ & $0.67 \pm 0.12$ & $0.68 \pm 0.10$ & $0.61 \pm 0.14^{*}$ & $0.71 \pm 0.12$ \\
\hline MAP (tor) & $89 \pm 22$ & $84 \pm 16$ & $88 \pm 20$ & $86 \pm 19$ & $86 \pm 20$ & $89 \pm 14$ \\
\hline $\mathrm{HR}\left(\cdot \min ^{-1}\right)$ & $80 \pm 7$ & $80 \pm 5$ & $85 \pm 6$ & $82 \pm 7$ & $86 \pm 16$ & $84 \pm 13$ \\
\hline
\end{tabular}

Mean $\pm \mathrm{SD}$

*Significantly different from pre-op $(\mathrm{p}<0.05)$. 


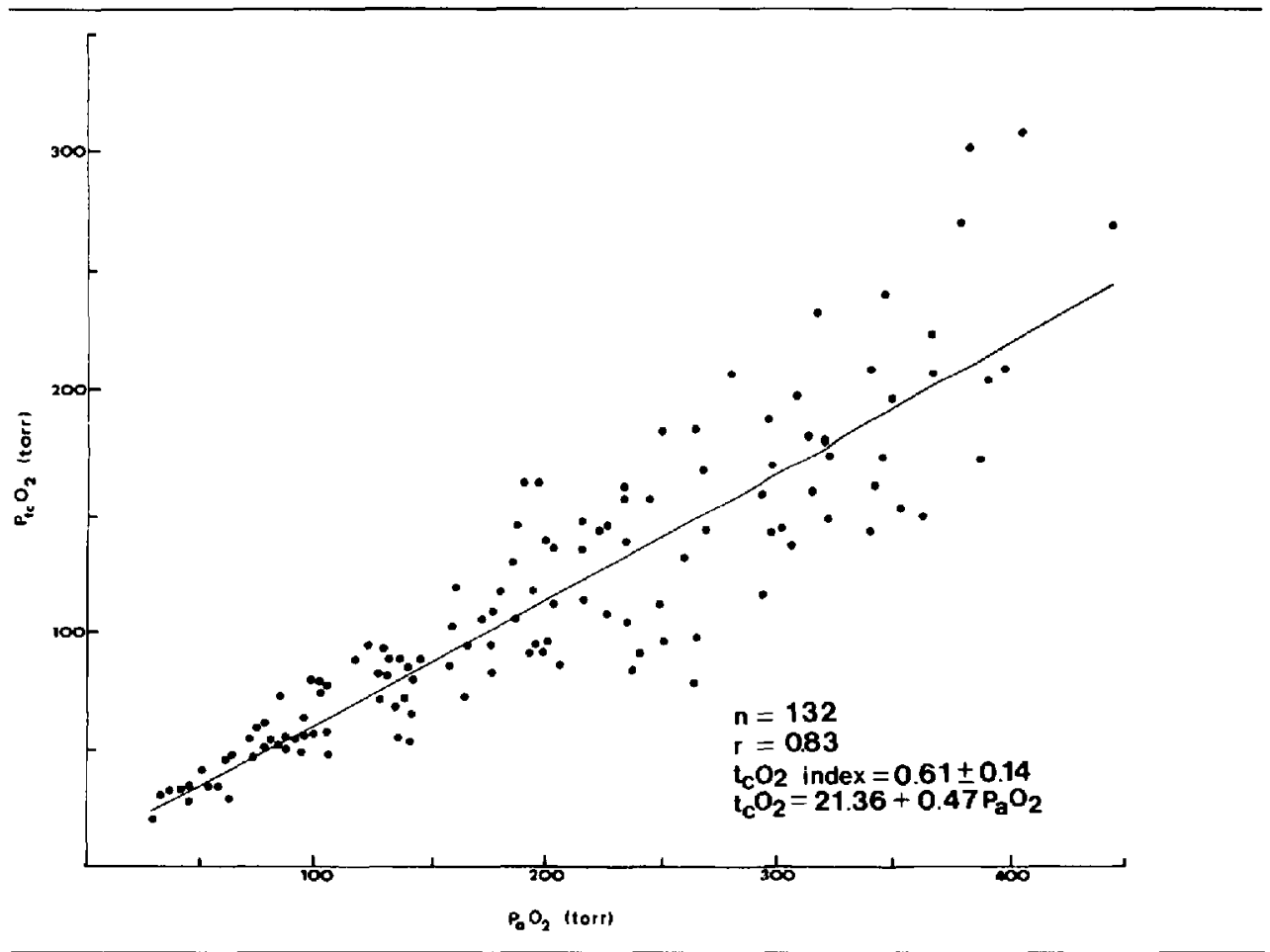

FIGURE 3 Intraoperative relationship between transcutaneous $\left(\mathrm{PtcO}_{2}\right)$ and arterial oxygen tension $\left(\mathrm{PaO}_{2}\right)$ during endobronchial anaesthesia (one-lung ventilation) for thoracotomy.

changes in $\mathrm{FIO}_{2}$ was $2.9 \pm 1.2$ minutes; the 99 per cent response time was $12.6 \pm 3.7$ minutes. There was no zero electrode drift recorded and average drift at 150 torr was $1.8 \pm 0.9$ torr/hr of study over 20 hours.

All $527 \mathrm{PtcO}_{2}$ readings were below the corresponding $\mathrm{PaO}_{2}$ values. $\mathrm{PtcO}_{2}$ changed in the same direction as $\mathrm{PaO}_{2}$ in 95 per cent of the paired measurements, in the opposite direction in three per cent and did not change in two per cent. A decrease in $\mathrm{PtcO}_{2}$ was associated with an increase in $\mathrm{PaO}_{2}$ on eight occasions; in five of these there was an associated decrease in MAP of ten torr or more. Increases in $\mathrm{PtcO}_{2}$ without any change in $\mathrm{FIO}_{2}$ occurred in eight instances; this was due to loose or dislodged skin sensors in all eight cases.

Mild erythema was noted at 100 per cent of the sensor sites after four hours but no other complications arose from the use of the $\mathrm{PtcO}_{2}$ monitor.

The initiation of one-lung ventilation was associated with a decrease in $\mathrm{PaO}_{2}$ and $\mathrm{PtcO}_{2}(\mathrm{r}=0.92$, $p<0.001$ ) in 25 of 30 patients. Four patients had a dramatic drop in the $\mathrm{PtcO}_{2}$ within seven minutes of the initiation of one-lung ventilation. The $\mathrm{PtcO}_{2}$ was the first parameter to change in each of these four cases, indicating the development of hypoxaemia or of impaired oxygen delivery. In one patient (Figure 5) the $\mathrm{PaO}_{2}$ was adequate throughout endobronchial ventilation; however, the $\mathrm{PtcO}_{2}$ dropped just prior to the development of hypotension associated with ST segment changes on the ECG monitor. Despite appropriate supportive measures, this patient sustained a documented myocardial infarction.

Figure 6 demonstrates the continuous $\mathrm{PtcO}_{2}$ tracing of one of the three patients who developed hypoxaemia unresponsive to oxygen insufflation into the operative, collapsed lung at $3 \mathrm{~L} \cdot \mathrm{min}^{-1}$ and $10 \mathrm{cmH}_{2} \mathrm{O}$ continuous airway pressure. ${ }^{9}$ Hypoxaemia was corrected only with the re-institution of two-lung ventilation. 


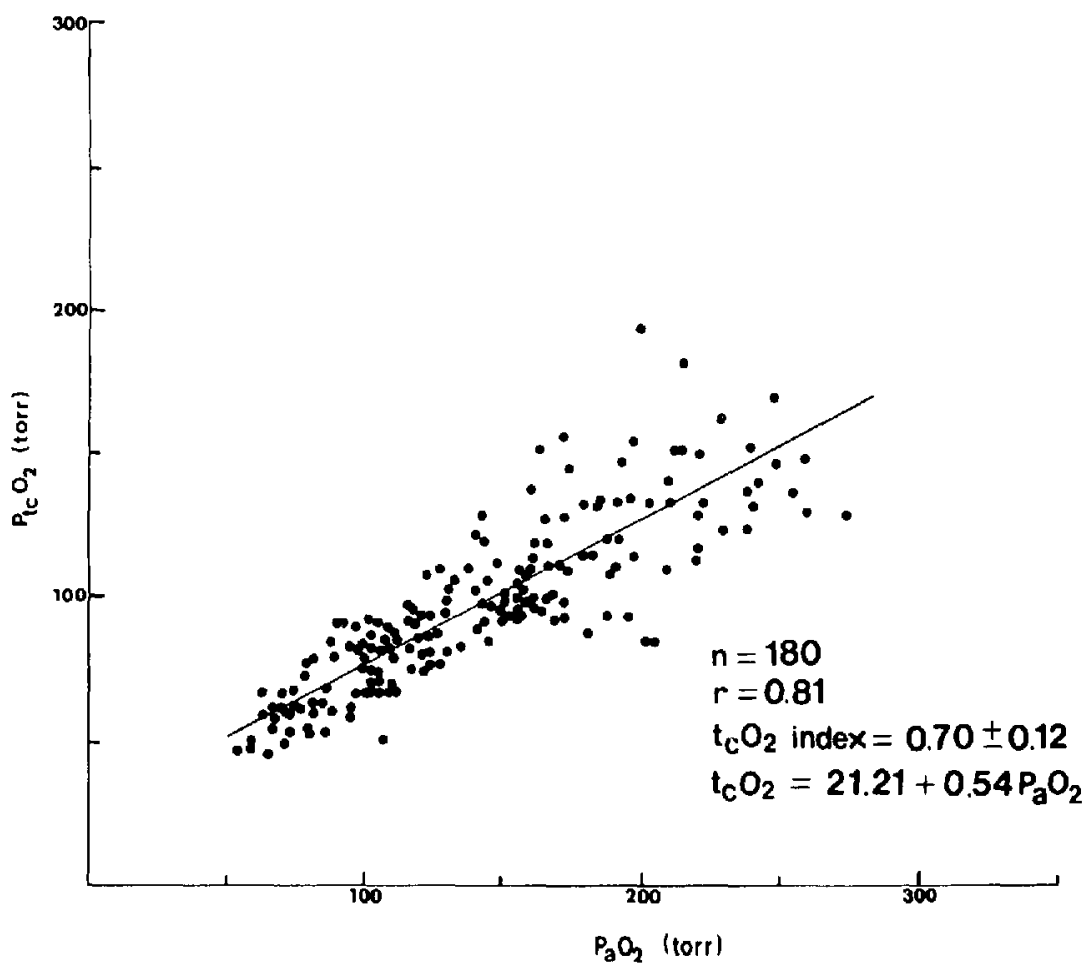

FIGURE 4 Relationship between transcutaneous $\left(\mathrm{PtcO}_{2}\right)$ and arterial oxgen tension $\left(\mathrm{PaO}_{2}\right)$ in the first 24 hours of postoperative recovery from thoracotomy,

\section{Discussion}

Studies demonstrating the value of $\mathrm{PtcO}_{2}$ monitoring as a reliable trend indicator of changes in $\mathrm{PaO}_{2}$ have been reviewed by Tremper. ${ }^{10}$ The present study confirms the correlation between $\mathrm{PtcO}_{2}$ and $\mathrm{PaO}_{2}$ for two-lung ventilation ${ }^{6}$ and for one-lung ventilation $^{8}$ during anaesthesia for thoracotomy. This relationship is sustained in the early recovery period after pulmonary resection.

All $\mathrm{PtcO}_{2}$ readings were consistently below the corresponding $\mathrm{PaO}_{2}$ values in our patients. Continuous recording of the $\mathrm{PtcO}_{2}$ thus provided a valuable estimation of the "minimum" $\mathrm{PaO}_{2}$ throughout anaesthesia and recovery.

In the four patients demonstrating marked decreses in $\mathrm{PtcO}_{2}$ during endobronchial anaesthesia, three had associated arterial hypoxaemia $\left(\mathrm{PaO}_{2}<\right.$ 40 torr) and one had significant hypotension (MAP $<50$ torr). In these four cases the $\mathrm{PtcO}_{2}$ was the first monitored parameter to change, thereby allowing early therapeutic intervention.

The ratio of $\mathrm{PtcO}_{2}: \mathrm{PaO}_{2}$, or $\mathrm{tcO}_{2}$ index, is determined by simultaneous $\mathrm{PtcO}_{2}$ and $\mathrm{PaO}_{2}$ measurements. In haemodynamically stable patients the $t_{\mathrm{CO}}$ index can then be applied to subsequent $\mathrm{PtcO}_{2}$ measurements to estimate $\mathrm{PaO}_{2} \cdot{ }^{4}$ In our series of patients the preoperative tc $\mathrm{O}_{2}$ index of $0.69 \pm 0.09$ is considerably lower than the value of $0.79 \pm 0.12$ previously reported for haemodynamically stable adults. ${ }^{4}$ The intraoperative $\mathrm{tcO}_{2}$ indices for our patients were also lower than those reported by Tremper $e t a l$. in their study of patients undergoing thoracotomy. ${ }^{8}$ This finding is consistent with the observation that $\mathrm{tcO}_{2}$ index decreases with advancing age: ${ }^{10}$ our patient population is older than in most other reports. ${ }^{2-5,8}$

The referenced American studies ${ }^{2-8}$ reported their findings based on a $\mathrm{PtcO}_{2}$ sensor temperature 


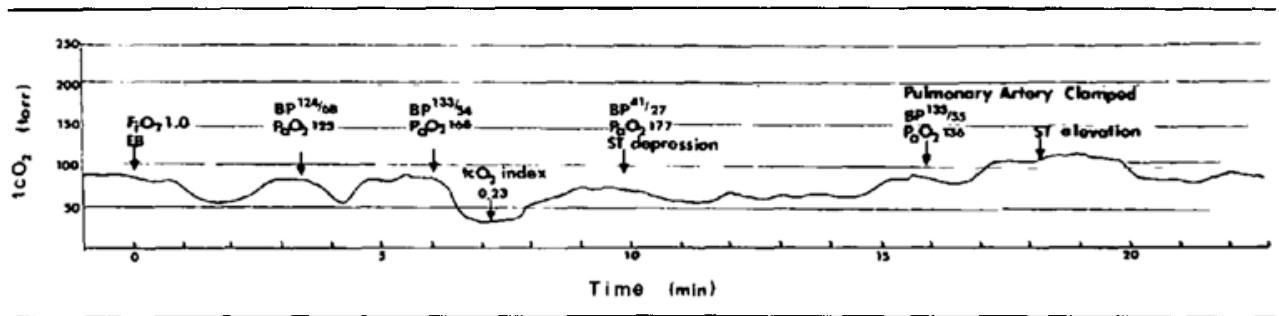

FIGURE 5 Continuous transcutaneous oxygen $\left(\mathrm{PtcO}_{2}\right)$ recording for the patient who sustained an intraoperative myocardial infarction. Comparative arterial oxygen tensions $\left(\mathrm{PaO}_{2}\right)$ are given. The drop in $\mathrm{PtcO}_{2}$ to 38 torr (corresponding to the tco index of 0.23 ) occurred 3 minutes before any change in heart rate or blood pressure were noted.

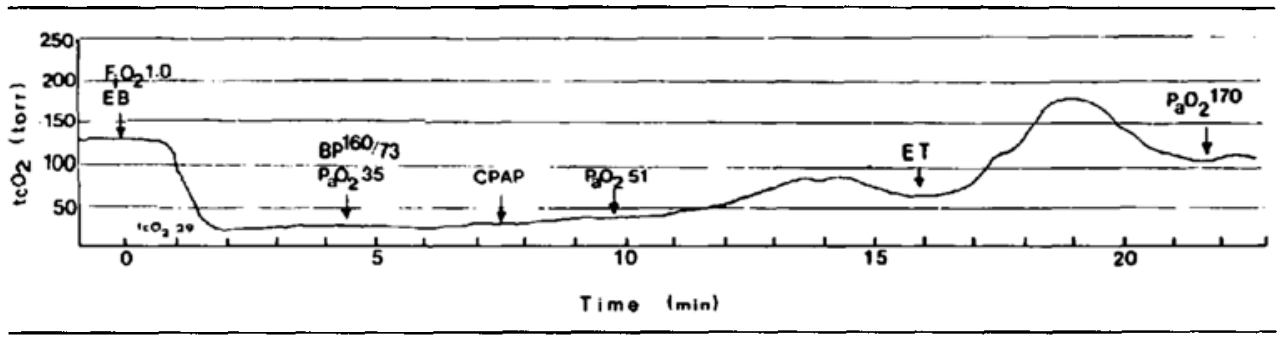

FIGURE 6 Continuous transcutaneous oxygen $\left(\mathrm{PtCO}_{2}\right)$ recording for a patient who developed severe arterial hypoxaemia after initiating endobronchial one-lung ventilation. $\mathrm{Both} \mathrm{PtcO}_{2}$ and $\mathrm{PaO}_{2}$ remained low despite continuous positive airway pressure (CPAP). Note the increase in $\mathrm{PtcO}_{2}$ with reinstitution of endotracheal two-lung ventilation (ET).

of $45^{\circ} \mathrm{C}$. Measured oxygen tension can vary as much as seven per cent per degree Centigrade between $42^{\circ} \mathrm{C}$ and $45^{\circ} \mathrm{C} .{ }^{11}$ In the present study the $\mathrm{PtcO}_{2}$ sensor temperature was maintained at $44^{\circ} \mathrm{C}$ maximum, as recommended by the manufacturer in compliance with Canadian standard guidelines for transcutaneous blood gas monitoring devices. Another Canadian study also used a sensor temperature of $44^{\circ} \mathrm{C} .{ }^{12}$ The lower sensor temperature may have affected the variability and contributed to the lower $\mathrm{PtcO}_{2}$ indices we observed.

A change in the relationship between $\mathrm{PtcO}_{2}$ and $\mathrm{PaO}_{2}$ during endobronchial one-lung ventilation is suggested by the significantly lower $\mathrm{tcO}_{2}$ index during this period. A lower $\mathrm{tcO}_{2}$ index during one-lung ventilation was also found by Tremper et $a l,{ }^{8}$ although possible causes were not discussed. A decrease in the $\mathrm{tcO}_{2}$ index has been documented to occur in association with decreased cardiac output, ${ }^{3-5}$ decreased body temperature, ${ }^{13,14}$ or increases in $\mathrm{PaO}_{2} \cdot{ }^{6,15} \mathrm{We}$ do not believe, however, that any one of these mechanisms adequately explains the decrease in $\mathrm{tcO}_{2}$ index observed in our patients during one-lung ventilation.
We did not measure cardiac output in our patients; other investigators have demonstrated that cardiac output does not change ${ }^{9}$ or increases slightly during one-lung ventilation. ${ }^{16}$ Such changes would not be expected to produce a decrease in the $\mathrm{tcO}_{2}$ index.

A decrease in body temperature, by causing a shift in the oxyhaemoglobin dissociation curve to the left, results in a decreased oxygen release to the tissues and a decrease in $\mathrm{PtcO}_{2}$ for a given $\mathrm{PaO}_{2}{ }^{1}{ }^{1} 14$ In our patients there was a gradual decrease in temperature throughout the study period, but the temperature during one-lung ventilation was not significantly lower than during two-lung ventilation either before or after the period of one-lung ventilation (see Table). Furthermore, when endotracheal ventilation was resumed following the period of endobronchial ventilation the $\mathrm{tcO}_{2}$ index rose in all but one patient. Hypothermia, therefore, cannot account for the decrease in $\mathrm{tcO}_{2}$ index observed during one-lung ventilation.

The $\mathrm{tcO}_{2}$ index can also change in association with high levels of $\mathrm{PaO}_{2}$ and both increases and decreases in the index have been noted. ${ }^{2,6,14,15}$ The 
mean $\mathrm{PaO}_{2}$ levels were not significantly different in the ET and EB time periods of our study, however, so that other factors must have caused the observed differences in $\mathrm{tcO}_{2}$ indices.

The $\mathrm{tcO}_{2}$ index is potentially affected by several factors associated with changing from two-lung to one-lung ventilation. In order to predict $\mathrm{PaO}_{2}$ as accurately as possible, a new $t c \mathrm{O}_{2}$ index should be determined some time after the initiation of onelung ventilation. The $\mathrm{tcO}_{2}$ index is a dynamic ratio that may be altered by changes in cardiac output, patient temperature and high levels of $\mathrm{PaO}_{2} . \mathrm{PtcO}_{2}$ monitoring cannot completely replace intermittent arterial blood gas analysis; nevertheless, we believe that $\mathrm{PtcO}_{2}$ monitoring is a reliable, continuous, non-invasive indicator of $\mathrm{PaO}_{2}$ in the perioperative management of patients undergoing thoracotomy involving endobronchial one-lung ventilation. $\mathrm{PtcO}_{2}$ monitoring provides the anaesthetist with an early warning of impending hypoxaemia or haemodynamic compromise thereby facilitating prompt and appropriate intervention.

\section{Acknowledgements}

The transcutaneous Lifespan \#100 monitor was provided by Biochem International (Waukesha, WI) through Mr. D. Berry of Overseas Monitor Corporation (Vancouver, B.C.). The support and cooperation of the Vancouver General Hospital Laboratory Services and the Department of Nursing (Heather Pavilion Recovery Room) are gratefully acknowledged.

\section{References}

1 Benumof JL, Alfery $D D$. Anesthesia for thoracic surgery. Chap. 40. In: Anesthesia, Miller RD, (Ed), Second Edition. New York, ChurchillLivingstone, 1986; 1371-1462.

2 Rafferry TD, Marrero O, Nardi D, Schachter EN. Mentelos $R,-N g$ eow $Y F$. Transcutaneous $\mathrm{PO}_{2}$ as a trend indicator of arterial $\mathrm{PO}_{2}$ in normal anesthetized adults. Anesth Analg 1982; 61: 252-5.

3 Dennhardt T, Fricke M, Mahal S, Huch A, Huch R, Transcutaneous $\mathrm{PO}_{2}$ monitoring in anesthesia. Eur J Intensive Care Med 1976; 2: 29-33.

4 Tremper KK, Shoemaker WC. Transcutaneous oxygen monitoring of critically ill adults with and without low flow shock. Crit Care Med 1981; 9 : 706-9.
5 Tremper $K K$, Waxman $K$, Bowman $R$, Shoemaker $W C$. Continuous transcutaneous oxygen monitoring during respiratory failure, cardiac decompensation, cardiac arrest and CPR. Crit Care Med 1980; 8: 377-81.

6 Gothgen I, Jacobsen E, Rasmussen JP. Transcutaneous oxygen measurement during thoracic anaesthesia. Acta Anaesthesiol Scand 1980; 24: 491-4.

7 Chung $M$, Lichtor $J L$, Rangachari $K$. Transcutaneous monitoring of $\mathrm{PO}_{2}$ and $\mathrm{PCO}_{2}$ during one-lung anesthesia. Anesthesiology 1984; 61: Al64.

8 Tremper KK, Konchigeri $H N$, Cullen BF, Kapur $P A$, Thangathurai D, Percival $C$. Transcutaneous monitoring of oxygen tension during one-lung anesthesia. J Thorac Cardiovase Surg 1984; 88 : 22-5.

9 Capan LM, Turndorf $H$, Patel C, Romanathan S, Acinapuro A, Chalon J. Optimization of arterial oxygenation during one-lung anesthesia. Anesth Analg 1980; 59: 847-51.

10 Temper $K K$. Transcutaneous $\mathrm{PO}_{2}$ measurement. Can Anaesth Soc J 1984; 31: 664-77.

11 Beran AV, Tolle CD, Huxtable RF. Cutaneous blood flow and its relationship to transcutaneous $\mathrm{O}_{2} / \mathrm{CO}_{2}$ measurements. Crit Care Med 1981; 9: 736-41.

12 Knill RL, Clement JL, Kieraszewicz HT, Dodgson $B G$. Assessment of two noninvasive monitors of arterial oxygenation in anesthetized man. Anesth Analg 1982; 61: 582-6.

13 Hutchinson DCS, Rocca G, Honeybourne D. Estimation of arterial oxygen tension in adult subjects using a transcutaneous electrode. Thorax 1981; 36: 473-7.

14 Kimmich $H P$, Kreuger $F$. Model of $\mathrm{O}_{2}$ transport through skin as basis for absolute transcutaneous measurement of $\mathrm{PaO}_{2}$. Acta Anaesthesiol Scan (Suppl) 1978; 68: 16-9.

15 Goeckenjan $G$, Strasser $K$. Relation of transcutaneous to arterial $\mathrm{PO}_{2}$ in hypoxemia, normoxemia and hyperoxemia. Biotelemetry 1977; 4: 77-87.

16 Thys DM, Cohen E, Eisenkraft JB, Kaplan JA. Hemodynamic effects of one-lung anesthesia during thoracic surgery. Anesthesiology 1984; 61 : A91. 


\section{Résumé}

La tension d'oxygène transcutanée $\left(\mathrm{PtcO}_{2}\right)$ était mesurée chez 30 patients cédulés pour résection pulmonaire élective requérant une ventilation d'un seul poumon durant l'anesthêsie. La mesure simultanée de la $\mathrm{PtcO}_{2}$ et de la tension artérielle d' oxygène $\left(\mathrm{PaO}_{2}\right)$ étaient faites en préopératoire (préop), peropératoire durant la ventila. tion des deux poumons par fube endotrachéal (ET) et lors de la ventilation endobronchique d' un seul poumon (EB). ainsi qu'en période postopératoire (postop). Il y avait une corrélation significative (r) entre la $\mathrm{PtcO}_{2}$ et la $\mathrm{PaO}_{2}$ à tous les temps étudiés: 0.97 (préop); 0.91 (ET); 0.83 (EB); 0.81 (postop). Il n'y avait aucune différence significative entre les indices transcutanés d'oxygène $\left({ }_{t} \mathrm{O}_{2}\right.$ index $\left.=\mathrm{PtcO}_{2} / \mathrm{PaO}_{2}\right)$ dans la période préopératoire $(0.69 \pm 0.09)$, ET $(0.68 \pm 0.10)$ et postop $(0.71 \pm$ 0.12 ). L'index ${ }_{10} \mathrm{O}_{2}$ était significativement plus bas lors de l'anesthésie avec un poumon unique $(0.61 \pm 0.14)$. La $\mathrm{Ptc}_{2}$ était constamment plus basse que la mesure correspondante du $\mathrm{PaO}_{2}$, fournissant ainsi une estimation continue de la valeur minimale de la $\mathrm{PaO}_{2}$ à travers l'anesthésie et le réveil. Chez quatre patients une diminution marquée de la $\mathrm{PtcO}_{2}$ est survenue juste après le début de la ventilation à un seul poumon. Chez trois de ces patients, ceci fut associé avec une hypoxémie artérielle tandis que dans l'ature elle s' est accompagnée d' un état hémodynamique compromis. Pour chacun, de ces quatre patienss la $\mathrm{PtcO}_{2}$ était le premier paramètre surveillé daccuser des changements. Etant donné qu'il y a un risque substantiel de développer de l'hypoxémie lors de l'anesthésie thoracique, la surveillance de la $\mathrm{PtCO}_{2}$ fournit un indice précieux d'avertissement contre l'hypoxémie ou l'état hémodynamique compromis facilitant ainsi une intervention thérapeutique précoce. 